\author{
Edward MALESZYK
}

\title{
Sieci zagraniczne jako element koncentracji handlu w Polsce ${ }^{1}$
}

Badania nad rola zagranicznych sieci handlowych $w$ procesach przeksztalceń $i$ modemizacji handlu w Polsce wskazuja na coraz wiekszy wplyw tych sieci na przebieg procesów koncentracji handlu. W artykule skupiono uwage na dwóch jej istotnych aspektach: koncentracji kapitatowej i organizacyjnej. Przez koncentrację kapitatowq rozumie siẹ kumulowanie zasobów materialno-technicznych, ludzkich i finansowych wśród największych przedsiębiorstw lub grup przedsiębiorstw, zaś organizacyjnq - skupienie funkcji zarzqdczych $i$ marketingowych $w$ grupie wspótpracujących ze sobq przedsiębiorstw $i$ wykonywanie tych funkcji centralnie przez integratora grupy.

Przedmiot rozważań ograniczono do procesów koncentracji w handlu detalicznym. Przejawiają się one bowiem rozwojem sieci filialnych przedsiębiorstw wielozakładowych i koncernów, handlu wielkopowierzchniowego oraz sieci zintegrowanych, czyli róźnych ugrupowań i związków organizacyjnych integrujących przedsiębiorstwa ze względu na wspólnotę celów i zadań. W odniesieniu do związków zintegrowanych analizę zawężono do detalicznych zrzeszeń zakupów i detalicznych grup zakupowych (integrujących detalistów z hurtownikami).

Do analizy procesów koncentracji kapitałowej zastosowano zestaw mierników i wyznaczników tej koncentracji w postaci: obrotów i udziałów rynkowych, zasobów kadrowych, sieci handlowej, kosztów i wyników finansowych najwię̧kszych przedsiębiorstw (koncernów) z sieciami filialnymi. Uwzględniono przy tym skalę inwestowania jako czynnika wzrostu zasobów przedsiębiorstw.

Natomiast w odniesieniu do procesów koncentracji organizacyjnej zbadano rodzaje i charakter koncentracji funkcji zarządczych i marketingowych zintegrowanych grup przedsiębiorstw. Dokonano oceny skuteczności tych funkcji poprzez pryzmat realizowanych przez integratora zadań i podejmowanych działań, osiąganych korzyści z dotychczasowych działań, uwzględniając przy tym pojawiające się trudności.

Badaniami objęto również rozwój sklepów wielkopowierzchniowych, jako przejaw koncentracji organizacyjno-technicznej na szczeblu detalu. Poddano je analizie zarówno w ramach sieci filialnych, jak i zintegrowanych.

Autor jest pracownikiem naukowym Instytutu Rynku Wewnętrznego i Konsumpcji w Warszawie.

1 Artykul stanowi syntezę wyników badań zawartych w opracowaniu autora pt. Sieci handlowe z kapitalem zagranicznym jako element koncentracji handlu, Warszawa 1999, IRWiK (maszynopis powielony). 
W badaniach empirycznych oprócz analizy materiałów statystycznych GUS wykorzystano również wyniki z przeprowadzonego w III kwartale 1999 r. wywiadu skategoryzowanego i pilotowanej ankiety. Badaniami tymi objęto menedżerów celowo dobranej grupy 16 znaczących sieci zagranicznych (Auchan, Billa, Carrefour, Edeka, Globi, Minimal, TTW Dom i Ogród, Adidas, Texaco, Agencja Handlowa „Sam”, Bressepol) i 12 znaczących sieci zintegrowanych z kapitałem krajowym (CBZ, Chata Polska, Delko, Lewiatan Detal, Rabat w Bielsku-Białej i Katowicach, Sklepy Familijne, Dolnośląska, Galicyjska i Mazowiecka Agencje Handlowe „Społem”, stowarzyszenia kupieckie Arena i Orbita).

\section{Sieci zagraniczne na tle ogólnych tendencji koncentracji w handlu}

W 1998 r. zwiększyła się liczba zarówno przedsiębiorstw własności zagranicznej i mieszanej (o 42\%), jak i - sieci sklepów tegoż sektora (o 11,1\%) i ich powierzchni sprzedażowej (o 74,2\%) w porównaniu z 1997 rokiem. W konsekwencji tych zmian spółki zagraniczne i mieszane skupiały w końcu $1998 \mathrm{r}$. 3027 sklepów (tj. 0,67\% ogólnej ich liczby) o lącznej powierzchni sprzedażowej 1,2 mln m2 (4,8\% powierzchni w skali kraju) i realizowały w 1998 r. 8,3\% sprzedaży detalicznej ogólem w Polsce. W handlu detalicznym działalność prowadziło 402 spółki własności zagranicznej i kolejne 47 - mieszanej, czyli łącznie 449 spółek o liczbie pracujących ponad 5 osób.

Analiza procesów koncentracji w handlu artykułami konsumpcyjnymi wymagała wyodrę̧nienia z ogółu podmiotów handlowych przedsiębiorstw największych, do których zakwalifikowano przedsiębiorstwa o zrealizowanych w 1998 r. obrotach od 50 do $99 \mathrm{mln}$ zł i od $100 \mathrm{mln}$ zł wzwyż. Wyodrę̧bnione w ten sposób 242 przedsiębiorstwa skupiały 19,6\% sprzedaży detalicznej w kraju, w tym 104 o obrotach od $100 \mathrm{mln}$ zł - 15,9\%. Znajdujące się w tej grupie 60 spółek własności zagranicznej miało większy udział w sprzedaży wśród przedsiębiorstw o obrotach od $100 \mathrm{mln}$ zł $(42,8 \%)$ niż - o obrotach od 50 do $99 \mathrm{mln}$ zł (15\%). Przytoczone wskaźniki świadczą o zbyt niskim poziomie koncentracji na rynku wewnętrznym oraz o tym, że na tẹ koncentrację duźy wpływ wywierają spółki zagraniczne.

O niewielkim stopniu zaawansowania procesów koncentracji świadczy również lista rankingowa 60 największych przedsiębiorstw detalicznych i ich grup w Polsce w 1998 r., specjalnie przygotowana do potrzeb opracowania. Przedsiębiorstwa i grupy przedsiębiorstw znajdujące się na tej liście realizując łącznie 30,9 mld zł obrotów (od $92 \mathrm{mln}$ zł do 6,5 mld zł) skupiały zaledwie $12,3 \%$ rynku detalicznego artykulów konsumpcyjnych w Polsce. Dziesięć największych firm, w większości z kapitałem zagranicznym (o obrotach od $776 \mathrm{mln}$ zł do $6,5 \mathrm{mld}$ zł), o łącznej wartości sprzedaży 18,0 mld zł (czyli ponad połowa obrotów firm objętych listą rankingową) miało $7,2 \%$ rynku detalicznego. Należą do nich (w kolejności według poziomu obrotów) tylko dwie spółki z kapitałem krajowym, tj. CPN SA i Ruch SA; pozostałe zaś z kapitałem zagranicznym: koncern niemiecki Metro AG ze spółkami Real, Praktiker 
i Tip Discount, koncern portugalski Jeronimo Martins Dystrybucja, spółka niemiecka Hit Centrala Usługowa, norweska Statoil, spółki z kapitałem francuskim - Géant (należąca do grupy Casino) i Auchan, spółki należące do koncernu niemieckiego Tengelmanna - Plus Discount i Obi Centrala Systemowa Superhobby, a także paliwowa spółka brytyjsko-holenderska Shell.

Dla porównania, obroty najwiẹkszych przedsiębiorstw detalicznych w Wielkiej Brytanii, ale o zdecydowanie wyższym przedziale wielkości przedsiẹbiorstw (o obrotach od 500 mln funtów szterlingów) stanowiły w 1994 r. 46,7\% rynku detalicznego; we Francji w 1991 r. (od 500 mln franków francuskich) 32,6\%; w Belgii w 1994 r. (od 1 mld franków belgijskich) - 27,1\%. Natomiast 10 największych grup detalistów w Szwajcarii w 1991 r. skupiały 32,9\% rynku detalicznego. Nawet przy bardzo rozdrobnionej strukturze handlu we Włoszech, udział rynkowy 9 największych grup przedsiẹbiorstw detalicznych w tym kraju w 1993 r. wynosił $11,7 \%^{2}$.

W przekroju rynków branżowych udział największych przedsiębiorstw handlowych, a w tym największych spółek zagranicznych jest zróżnicowany. Zdecydowanie przeważający udział mają: zaledwie 11 spółek w sprzedaży detalicznej przedsiębiorstw o obrotach od $100 \mathrm{mln}$ zł na rynku żywnościowym, alkoholi i wyrobów tytoniowych $(65,3 \%)$ oraz wyłączny (tj. 100\%) na rynku kosmetyczno-toaletowym.

Wyniki analizy koncentracji sprzedaży w dużych przedsiębiorstwach w przekroju wojewódzkim wykazują natomiast, że najwyższą koncentracją „odznaczają" się województwa wysoko zurbanizowane i uprzemysłowione. Należą do nich: mazowieckie (gdzie udzial przedsiębiorstw o obrotach ponad $50 \mathrm{mln}$ zf w ogólnej sprzedaży detalicznej podmiotów o liczbie pracujących ponad 5 osób województwa wynosi $71,9 \%)$, śląskie (42\%), zachodniopomorskie $(29,3 \%)$, małopolskie (29\%), wielkopolskie (28\%), świętokrzyskie $(22,3 \%)$ i pomorskie $(20,4 \%)$. W największych miastach wymienionych województw obserwuje się wzmożoną ekspansję spółek zagranicznych z sieciami handlowymi.

Analiza koncentracji kapitału rzeczowego (sieci handlowej) i ludzkiego ujawniła przy tym, że spółki zagraniczne najwyższe omawiane zasoby skupiają na rynku kosmetyczno-toaletowym i żywnościowym, zasoby kadrowe na rynku mebli i sprzętu oświetleniowego - w relacji do zasobów ogółu największych przedsiębiorstw handlowych (o obrotach od $50 \mathrm{mln}$ zł wzwyż).

Generalnie można stwierdzić, że blisko $40 \%$ - udział spólek w liczbie pracujących i $50 \%$ - udział w powierzchni sprzedażowej ogółu przedsiębiorstw dużych (o obrotach od $50 \mathrm{mln} \mathrm{zl}$ ), potwierdza istotny wpływ tych spółek na procesy koncentracji kapitału rzeczowego i ludzkiego w handlu detalicznym.

O relatywnie większej koncentracji kapitału rzeczowego i ludzkiego w spólkach zagranicznych świadczą ponadto dane porównawcze, przedstawiające przeciętne zasoby kadrowe i sieciowe przypadające na 1 przedsiębiorstwo duże (o obrotach od $50 \mathrm{mln}$ zł), zawarte w tablicy 1.

2 dane Eurostat zawarte w Retail Trade in the Economic Area including Switzerland. Country reports. Amsterdam $1996 \mathrm{r}$. 
Zasoby kadrowe i sieciowe przypadające na.1 przedsiębiorstwo handlowe o obrotach powyżej $50 \mathrm{mln}$ zl w 1998 r. (w przekroju rynków branżowych)

\begin{tabular}{|c|c|c|c|c|c|c|}
\hline \multirow[b]{2}{*}{ Branża } & \multicolumn{3}{|c|}{ ogólem } & \multicolumn{3}{|c|}{ w tym wlasnoset zagranieznej } \\
\hline & $\begin{array}{c}\text { liczba } \\
\text { pracujacych } \\
\text { w shlepach }\end{array}$ & $\begin{array}{c}\text { powierzchnia } \\
\text { sprzedażowa } \\
\text { sklepow } \\
\text { w tys. } \mathrm{m}^{2}\end{array}$ & $\begin{array}{l}\text { powierzchnia } \\
\text { magazynów } \\
\text { handlowych } \\
\text { zamkniçtych } \\
\text { w tys. } \mathrm{m}^{2}\end{array}$ & $\begin{array}{c}\text { liczha } \\
\text { pracujących } \\
\text { w sklepach }\end{array}$ & $\begin{array}{l}\text { powierzchnia } \\
\text { sprzedażowa } \\
\text { sklepów } \\
\text { w tys. } \mathrm{m}^{2}\end{array}$ & $\begin{array}{l}\text { powierzchnia } \\
\text { magazynow } \\
\text { handlowych } \\
\text { zamknięych } \\
\text { w tys. m² }\end{array}$ \\
\hline $\begin{array}{l}\text { Żywnosc, napoje alkoholowe i } \\
\text { bezalkoholowe, wyroby tyzonionse }\end{array}$ & 531 & 9,9 & 13,2 & 1082 & 22,9 & 16,0 \\
\hline Odziez i antykuhy wbókiennicze & 207 & 5.1 & 2,8 & 142 & 2.7 & \\
\hline Meble i sprzęt oświetleniowy & 222 & 16.1 & - & 711 & 40.4 & \\
\hline $\begin{array}{l}\text { Artykuly radiowo-telewizyjne i } \\
\text { sprzęt gospodarstwa domowego }\end{array}$ & 221 & 7,4 & 13,2 & . & . & \\
\hline Pojazdy mechaniczne & 19 & 0,8 & 1,3 & 9 & 0.5 & 2.1 \\
\hline Paliwa & 464 & 6,0 & 4,9 & 310 & 0,06 & 0,4 \\
\hline Onólem kraj & 229 & 6,0 & 16,9 & 475 & 12.0 & 14,8 \\
\hline
\end{tabular}

1/ dane dotyczą 242 przedsiębiorstw, w tym 60 - własności zagranicznej

Źródło: dane GUS i obliczenia własne

Na rynku wewnętrznym w Polsce wciąż zdecydowanie przeważają przedsiębiorstwa jednozakładowe, przy czym polowa podmiotów handlowych prowadzi działalność bez sklepów, a z pozostałej części aż 98,8\% dysponuje 1-2 sklepami. Przedsiębiorstwa z sieciami handlowymi (z co najmniej 10 sklepami) stanowily w 1998 r. zaledwie $0,12 \%$ ogółu podmiotów detalicznych. Ta grupa 1005 podmiotów użytkując 17,1 tys. sklepów o łącznej powierzchni sprzedażowej 2,2 mln $\mathrm{m}^{2}$ skupiała w 1998 r. 3,8\% ogólnej liczby i 8,8\% powierzchni sprzedażowej sklepów w kraju. Spółki zagraniczne z sieciami stanowiły 2,4\% liczby tej grupy przedsiębiorstw, skupiając jednocześnie $22 \%$ jej powierzchni sprzedażowej.

O potencjale koncentracji zwłaszcza kapitałowej decyduje w znacznym stopniu kondycja ekonomiczno-finansowa przedsiębiorstw. Dostępne dane GUS pozwoliły na porównanie ogólnej sytuacji w tym zakresie przedsiębiorstw detalicznych o obrotach od $50 \mathrm{mln}$ zł wzwyż, w tym spółek zagranicznych na tle ogólu przedsiębiorstw detalicznych składających sprawozdanie finansowe (tabl. 2). 
Sytuacja ekonomiczno-finansowa przedsiębiorstw handlu detalicznego o obrotach powyżej $50 \mathrm{mln}$ zl w $1998 \mathrm{r}$. na tle ogólu przedsiębiorstw handlu detalicznego w Polscel

\begin{tabular}{|c|c|c|c|c|}
\hline \multirow[b]{2}{*}{ Wyszczególnienie } & \multirow[b]{2}{*}{ ogólem } & \multirow{2}{*}{$\begin{array}{l}\text { w tym spotki } \\
\text { z kapitalem } \\
\text { zagranicznym }\end{array}$} & \multicolumn{2}{|c|}{ o obrotach od $50 \mathrm{mln}$ zt } \\
\hline & & & ogólem & $\begin{array}{c}\text { w tym spolki } \\
\text { z kapitalem zagranicznym }\end{array}$ \\
\hline $\begin{array}{l}\text { Liczba przedsiębiorstw objętych } \\
\text { badaniem }\end{array}$ & 7718 & 699 & 92 & 34 \\
\hline $\begin{array}{l}\text { Przychody z calokształtu } \\
\text { działalnosci (w mln zd) }\end{array}$ & 54069,2 & 9487,1 & 20272,5 & 7391,7 \\
\hline $\begin{array}{l}\text { Koszty uzyskania przychodów } \\
\text { (w mln zl) }\end{array}$ & 53532,9 & 9927,4 & 20279,7 & 7803,2 \\
\hline $\begin{array}{l}\text { Saldo wyniku finansowego } \\
\text { (w mln zł) } \\
\text { - brutto } \\
\text { - netto }\end{array}$ & $\begin{array}{l}461,0 \\
100,0\end{array}$ & $\begin{array}{r}-437,8 \\
-504,5\end{array}$ & $\begin{array}{r}-82,1 \\
-243,9\end{array}$ & $\begin{array}{l}-410,1 \\
-442,2\end{array}$ \\
\hline $\begin{array}{l}\text { Rentowność obrotu (w \%) } \\
\text { - brutto } \\
\text { - netto }\end{array}$ & $\begin{array}{l}0,9 \\
0,2\end{array}$ & $\begin{array}{r}-4,6 \\
-5,3\end{array}$ & $\begin{array}{l}-0,4 \\
-1,2\end{array}$ & $\begin{array}{l}-5,5 \\
-6,0\end{array}$ \\
\hline $\begin{array}{l}\text { Liczba przedsiębiorstw } \\
\text { wykazujących zysk } \\
\text { - brutto } \\
\text { - netto }\end{array}$ & $\begin{array}{l}5135 \\
5066\end{array}$ & $\begin{array}{l}385 \\
369\end{array}$ & $\begin{array}{l}63 \\
61\end{array}$ & $\begin{array}{l}15 \\
14\end{array}$ \\
\hline
\end{tabular}

1/ Dotyczy przedsiębiorstw składających sprawozdania bilansowe

Źródło: dane GUS

Wyniki analizy wykazują, że zarówno cała grupa największych przedsiębiorstw, jak też spółki zagraniczne osiągają per saldo straty. Jednocześnie ponad 44\% objętych badaniem spółek i $68 \%$ przedsiębiorstw detalicznych ogółem o obrotach ponad $50 \mathrm{mln}$ zł wykazuje zysk brutto, a odpowiednio $41 \%$ i $66 \%$ - zysk netto.

Pogłębiona analiza (oparta na materiałach źródłowych do list rankingowych opublikowanych w 1999 r. w „Gazecie Bankowej”, „Rzeczpospolitej”, „Polityce”, „Nowym Życiu Gospodarczym”) ujawnia relatywnie wysoki poziom inwestowania w spółkach zagranicznych w porównaniu do największych przedsiębiorstw z kapitałem krajowym. I tak np. syntetyczny miernik charakteryzujący poziom tego inwestowania, czyli wskaźnik inwestowania (stosunek nakładów do przychodów ogółem), w polskich przedsiębiorstwach, które udzieliły informacji, wynosił w 1998 r. od $0,73 \%$ do $6,98 \%$, zaś w spółkach zagranicznych od $1,31 \%$ do $20,99 \%$. 


\section{Sieci zagraniczne na rynkach branżowych}

Wiẹszość spółek zagranicznych z sieciami handlowymi na naszym rynku ma charakter sieci globalnych. Spośród 34 spólek i koncernów z kapitałem zagranicznym znajdujących się na omawianej wyżej liście rankingowej 60 największych detalistów w Polsce, aż 30 uczestniczy w rynkach wielu krajów europejskich i innych kontynentów. Decydujący wpływ sieci zagranicznych na procesy koncentracji handlu w Polsce zaznacza się przede wszystkim poprzez:

- polaryzację sieci zdywersyfikowanych i ich skupianie w wąskiej grupie koncernów zdobywających pozycję liderów rynkowych, np. Metro AG, Tengelmann;

- rozwój sieci masowej sprzedaży zwlaszcza form handlu wielkopowierzchniowego (hipermarkety, supermarkety, domy dyskontowe), wysokowydajnego i efektywnego w stosunku do potrzeb i preferencji konsumentów. Sieci te spełniają decydującą rolę wśród sieci zagranicznych w procesach koncentracji organizacyjno-technicznej handlu w Polsce;

- stopniowy rozwój sieci na obszarach rynku, gdzie nastẹpuje dyferencjacja potrzeb, wyodrẹbnianie oddzielnych grup nabywców i segmentów rynku, postępuje proces indywidualizacji obsługi, któremu towarzyszy kreowanie zróżnicowanych i innowacyjnych form handlu, w tym nowych rodzajów sieci w odkrywanych niszach rynkowych, np. samoobsługowe domy handlowe „Dom i Ogród”, sklepy „convenience”, samoobslugowe domy multimedialne. $\mathrm{Z}$ punktu widzenia procesów koncentracji istotne znaczenie ma śledzenie rozwoju sieci globalnych w trzech aspektach: w koncernach o zdywersyfikowanej działalności, sieci handlu wielkopowierzchniowego oraz sieci tworzących łańcuchy sklepów o określonej specjalizacji branżowej.

Obecnie do znaczących sieci handlowych koncernów o zdywersyfikowanej działalności należą:

- sygnalizowany wyżej koncern zachodnioniemiecki Metro AG - operator poprzez swoje spótki podporządkowane - wielkopowierzchniowych magazynów cash and carry Makro Cash and Carry Poland SA (15 magazynów - 250 tys. $\mathrm{m}^{2}$ powierzchni handlowej; obroty $5,4 \mathrm{mld}$ zł; 7,5 tys. pracujących osób w 1998 r); hipermarketów Real (10 hipermarketów - 101 tys. $\mathrm{m}^{2}$ powierzchni sprzedażowej; obroty $790 \mathrm{mln}$ zł w $1998 \mathrm{r}$ ); domów handlowych Dom i Ogród - Praktiker (6 - ok. 48 tys. $\mathrm{m}^{2}$ powierzchni sprzedażowej; obroty $138 \mathrm{mln}$ zł; 800 pracujących osób w 1998 r.), sklepów multimedialnych - Media Markt (6 w końcu 1999 r.), sklepów ze sprzętem komputerowym - Vobis Microcomputer (110 w 1998 r.), domów mody spółki z o.o. Adler (10 w końcu 1999 r.), centrów handlowych M1 (5 w pol. 1999 r.);

- grupa francuska Auchan, reprezentowana przez spółki Auchan Polska z siecią 4 hipermarketów i ośrodków (centrów) handlowych, Leroy Merlin z siecią 5 domów handlowych Dom i Ogród oraz polsko-francuską spółkẹ Robert z siecią 15 supermarketów i sklepów delikatesowych (w końcu 1999 r); 
- sygnalizowany wyżej zachodnioniemiecki koncern Tengelmann z siecią 83 sklepów dyskontowych żywnościowych (w końcu 1998 r.), należących do spółki Plus Discount oraz z siecią 6 domów handlowych Dom i Ogród (w końcu 1998 r.), spólki Obi Centrala Systemowa Superhobby;

- spółka EMPiK reprezentująca wraz z innymi spółkami holenderski koncern Eastbridge NV, prowadząca sieci: 6 domów handlowych i 41 Klubów Miẹdzynarodowej Prasy i Książki, 4 salonów z zabawkami i gadżetami „Mickey and Friends", 54 laboratoriów fotograficznych (ze sprzedażą aparatów i akcesoriów fotograficznych), 9 salonów optycznych Optyk Express.

Odrębną grupę sieci zdywersyfikowanych tworzą stacje paliw i towarzyszące im sklepy „convenience” („wygody”), należące do czołowych koncernów paliwowych o zasięgu europejskim i globalnym. Największe udziały w rynku detalicznym mają sieci koncernu norweskiego Statoil; brytyjsko-holenderskiego Shell (który we wrześniu 1999 r. wykupił stacje paliw i sklepy „convenience" obecnego w Polsce koncernu amerykańskiego Texaco), spółki z kapitałem niemieckim Aral; koncernu fińskiego Neste Oil i szwedzkiego Preem Petroleum AG (reprezentowanego w Polsce przez spółkẹ Preem Polska).

Największymi zaś sieciami stacji benzynowych i sklepów „convenience” w Polsce dysponują obecnie spółki: Shell, Statoil i British Petroleum. One właśnie przewidują dalszy dynamiczny rozwój tych sieci, aby osiągnąé ich stan docelowo w granicach 150-200.

Na rynku artykułów żywnościowych, napojów alkoholowych i bezalkoholowych oraz wyrobów tytoniowych działalność prowadzą 24 znaczące sieci zagraniczne, w tym 20 o charakterze międzynarodowym i globalnym, w większości jako sieci filialne koncernów miẹdzynarodowych, trzy systemy franchisingowe (Costcutter, Rema 1000 i Spar) oraz dwa zrzeszenia detalistów (E. Leclerc Pergranso, Intermarche). Pozostałe cztery łańcuchy sklepowe należą do spólek polsko-zagranicznych typu joint ventures (Alti, ETC Jahr Verlag, Frapo Dystrybucja, „Społem” Zatoka).

Spośród 24 omawianych łańcuchów sieci zagranicznych 18 znajduje siẹ na liście rankingowej największych detalistów. Zrealizowały one w 1998 r. obroty w wysokości około $10 \mathrm{mld}$ zl, co stanowiło $8,3 \%$ sprzedaży detalicznej artykułów żywnościowych, napojów alkoholowych i bezalkoholowych oraz "wyrobów tytoniowych w Polsce. Największe udziały tego rynku detalicznego miały w 1998 r:

- koncern portugalski Jeronimo Martins z ogólnokrajową siecią sklepów dyskontowych Biedronka i hipermarketów Jumbo (1,04\%);

- koncern niemiecki Metro również z podobnymi sieciami Tip i Real na terenie całego kraju $(1,02 \%)$;

- spółka z kapitałem niemieckim Hit z hipermarketami o tej samej nazwie, usytuowanymi w największych miastach Polski $(0,99 \%)$;

- spółki z kapitałem francuskim z sieciami hipermarketów: Geant (Casino) $0,78 \%$, Auchan $-0,62 \%$, Carrefour $-0,56 \%)$; 
- koncern niemiecki Tengelmann z siecią sklepów dyskontowych Plus na terenie całego kraju $(0,62 \%)$;

- filia koncernu holenderskiego Ahold Polska Sp. z o.o. z sieciami supermarketów Max i sklepów dyskontowych Sesam na terenie Polski Poludniowej $(0,54 \%)$.

Do tego grona zalicza się również spółki: Billa i Minimal (z ogólnokrajowymi sieciami supermarketów i hipermarketów) należące do koncernu niemieckiego Rewe; z kapitałem francuskim Leclerc (hipermarkety), belgijskim Globi (supermarkety dyskontowe), norweskim Rema 1000 (sklepy dyskontowe funkcjonujące według zasad franchisingu), brytyjskim Tesco-Savia (hipermarkety, sklepy dyskontowe), duńskim Netto (sklepy dyskontowe), niemieckim Edeka (hipermarkety, supermarkety i sklepy dyskontowe) oraz francuskim Intermarche (sklepy dyskontowe), które w 1998 roku miały 2,0\% rynku detalicznego żywności, napojów i wyrobów tytoniowych w Polsce.

Spółki z kapitałem zagranicznym są prawie wyłącznymi operatorami hipermarketów w Polsce (50 hipermarketów w końcu 1998 r. sposród ogólu 54 występujących w Polsce), skupiając 99\% sprzedaży realizowanej w hipermarketach ogólem. Ponadto spólki te skupiają według szacunków 1/3 liczby supermarketów ogólem w kraju i wiẹkszość sklepów dyskontowych. Największą dynamiką rozwoju charakteryzują się zagraniczne sieci hipermarketów oraz łańcuchy sklepów dyskontowych, co wynika zarówno z dotychczasowego przebiegu tempa uruchamiania tych sklepów, jak i deklarowanych przez spółki zagraniczne planów rozwojowych.

Oprócz sklepów masowej sprzedaży spółki te kreują sieci wyspecjalizowane w niszach rynku żywnościowego, alkoholi i używek, jak np. sklepy z herbatą, kawą (Demmer's Teahouse, Whittard), z alkoholami (Allied Domecq Spirits and Hine, Seagram), z wyrobami cukierniczym (Fleury Michon).

$\mathrm{Na}$ rynku artykułów nieżywnościowych najwiẹkszymi obszarami ekspansji sieci międzynarodowych i globalnych są przede wszystkim rynki branżowe:

- z artykułami do wyposażenia i wykończenia mieszkań i do ogrodu,

- odzieżowo-obuwniczy,

- z artykułami zaspokajającymi potrzeby rekreacji, wypoczynku, rozrywki, kulturalne.

Nieco mniejszym zainteresowaniem spółek zagranicznych cieszą się natomiast sektory rynku: kosmetycznego, odzieży i sprzętu sportowo-turystycznego; nikłym zaś - sieci wielobranżowe typu domów towarowych.

Największą ekspansję sieci zagranicznych (w większości globalnych) odnotowuje się na rynku artykułów do wnętrz mieszkalnych i ogrodu. Do najważniejszych operatorów tych sieci, w postaci samoobslugowych domów handlowych - supersklepów Dom i Ogród, należą obecnie spółki: Praktiker (6 w końcu 1998, wzrost do 10 w końcu 1999 i 40 w końcu 2002 r.), Obi Superhobby (6 w 1998 r., wzrost do 12 w 1999 r. i 50 w 2002 r.), Castorama (3 w 1998 r., 8 w 1999 r., wzrost docelowo do 17), Leroy Merlin (2 w 1998 r., 5 w 1999 r.), TTW (3 w 1998 r., 4 w 2000 r.). Znaczną dynamikę rozwoju wykazują rów- 
nież sieci zagraniczne z wyspecjalizowanymi domami handlowymi (meblowymi, ze sprzętem radiowo-telewizyjnym, gospodarstwa domowego, elektronicznym powszechnego użytku), do których należą przede wszystkim sieci Ikea Retail (6 domów meblowych w 1998 r., wzrost do 12), Elektroland należące do spółki Braborg (4 domy handlowe w 1999 r.), Euro Net (31 sklepów w polowie 1999 r.), Panasonic i Sony.

Na rynku odzieżowo-obuwniczym dominują sieci z modną odzieżą i obuwiem znanych marek swiatowych. Do znaczących operatorów zagranicznych tych sieci należy zaliczyć spółki z kapitałem niemieckim Adler, Benetton Central Europe, Reno Obuwie; spółki organizujące sieci sklepów obuwniczych But Hala (część koncernu francuskiego Andre), obuwia luksusowego Bata (z kapitałem kanadyjskim); spółki z kapitałem włoskim organizujące sieci sklepów odzieżowych Arnold Happening, Max Mara, Nico Polska, Terranova i inne spółki - operatorzy tych sklepów, jak np. Cubus (część norweskiego koncernu tekstylnego Varner Gruppen), Deni Cler (sieć franchisingowa), Royal Collection,

W rynku artykułów zaspokajających potrzeby rekreacji, wypoczynku, rozrywki, hobby i kulturalne uczestniczą przede wszystkim sieci spółek zagranicznych:

- omawianej wyżej EMPiK,

- Bertelsmann Distribution (księgarnie Świat Książki),

- Extrapole z salonami multimedialnymi (obejmującymi szeroki i pogłębiony asortyment książek, plyt, videokaset, artykułów papierniczych, prasy itp.),

- omawianych wyżej Media Markt i Vobis Microcomputer,

- Karen Notebook z siecią sklepów firmowych oferujących przenośne komputery osobiste,

- Hewlett Packard rozwijająca sieć sklepów ze sprzętem komputerowym, oprogramowaniem, drukarkami, fotokopiarkami,

- z artykułami fotograficznymi: Kodak oraz Fujifilm.

Na rynku kosmetyczno-toaletowym zaznaczają swoją obecność przede wszystkim sieci zagraniczne trzech spółek:

- Polbity z 377 drogeriami samoobsługowymi - Drogerie Natura (stan w końcu 1998 r.), tworzących łańcuch sklepów stowarzyszonych;

- Rossmanna operatora 58 drogerii samoobsługowych w kraju, który w 1998 r: miał $2,1 \%$ detalicznego rynku artykułów kosmetyczno-toaletowych w Polsce;

- Yves Rocher Polska (francuska sieć franchisingowa), która zorganizowala lańcuch 27 luksusowych perfumerii (w końcu 1998 r.).

Do znaczących zaś sieci zagranicznych na rynku odzieży sportowo-turystycznej i sprzętu sportowego można zakwalifikować sklepy spółek: z kapitałem niemieckim Adidas (260 sklepów w 1998 r.); Go Sport (część francuskiej firmy Go Sport); Intersport Polska (należącej do norweskiego koncernu Gresvig Asa Group) oraz z kapitałem: brytyjskim Lee Cooper, amerykańskim Levi Strauss i szwajcarskim Big Star. 
Dużą dynamiką rozwoju charakteryzuje się także specjalistyczna sieć detaliczno-hurtowa z artykułami do wyposażenia biur amerykańskiego koncernu Retail Investment Concepts, wystẹpująca w Polsce pod nazwą Office Depot. Do września 1999 r. funkcjonowały dwie odrębne sieci tego koncernu: łańcuch sklepów Office Depot i centra zaopatrzenia biur Office Centres.

Jedynym przedsiębiorstwem zagranicznym, które podjęło inicjatywę zorganizowania w Polsce sieci własnych domów towarowych, jest jak dotychczas brytyjski koncern Marks and Spencer Plc. Po upływie dwóch lat od założenia przez ten koncern spółki Marks and Spencer Franchice uruchomił on w Warszawie pierwszy dom handlowy. Zamierza uruchamiać domy towarowe i handlowe w centrach największych miast w Polsce, jak w: Poznaniu, Łodzi, Wroclawiu i Krakowie.

Do niedawna funkcjonująca największa krajowa sieć 32 domów towarowych i handlowych Centrum zmieniając swój status własności (70\% udziałów kupiła bowiem firma Handlowy Investment Centrum SA, z której pakiet większościowy należy do holenderskiej spółki Eastbridge N.V.) stała się siecią z kapitałem zagranicznym.

\section{Sieci zagraniczne a zintegrowane sieci z kapitałem krajowym}

Omówione wyniki badań wykazują, że sieci zagraniczne (w większości globalne) mają przewagę nad sieciami krajowymi zarówno pod względem udziałów rynkowych, jak i zasobów kadrowych i materialno-technicznych.

Jedynie na czterech rynkach branżowych obecność swoją zaznaczają sieci krajowe. Należą do nich, na rynku:

- żywnościowym, sieć filialna wielozakładowego przedsiębiorstwa Market Pozperito SA w Poznaniu, która w 1998 r. miała 0,17\% udziału w detalicznym rynku artykułów żywnościowych, alkoholi i wyrobów tytoniowych. Sieć tę tworzą (według stanu na koniec 1998 r.) 14 supermarketów Market Pozperito, 4 hipermarkety Hipo i 8 sklepów dyskontowych „Raz dwa” o łącznej powierzchni sprzedażowej 21,4 tys. $\mathrm{m}^{2}$. Dalszy rozwój tej sieci wiąże się z wydzierźawieniem i modernizacją przejętych od PHS - Interkontakt 150 sklepów Sama. Na omawianym rynku znaczącą rolę pełnią również sieci filialne o charakterze lokalnym i subregionalnym: 11 spółdzielni spożywców „Społem” (PSS w Białymstoku, Szczecinie, Rzeszowie, Bydgoszczy, Bielsku-Białej; WSS Warszawa - Żoliborz; PSS w Poznaniu, Kielcach; WSS - Warszawa Praga Poludnie; PSS w Tarnowie i Mokpol w Warszawie), które dysponowały w końcu 1998 r. ponad 500 sklepami i skupiały $1,4 \%$ udziału w rynku, a także sieci (o niedużych zasobach) Krakchemii SA, Frąc Delikatesy Centrum SA, Aldika. Do grona tego należy zaliczyć również sieci ogólnokrajowe przedsiębiorstw Marc Pol (65 sklepów w końcu 1998 r.), Pekpol (24 sklepy mięsne i spożywcze w końcu 1998 r.) i sieć regionalną Lider Market (15 supermarketów w Polsce Południowej - stan z września 1999 r); 
- artykułów do wnętrz mieszkalnych i ogrodu - ogólnokrajowe sieci: supersklepów Nomi - Dom i Ogród (16 w końcu 1998 r., wzrost docelowo do 50) oraz sklepów z dywanami, wykładzinami i artykułami do wykończenia mieszkań spółki Komfort (100 sklepów w pol. 1999 r.);

- paliwowym - ogólnokrajowe sieci stacji benzynowych i towarzyszących im sklepów o charakterze „convenience” Polskiego Koncernu Naftowego (powstałego z polączenia CPN i Petrochemii Płock w maju 1999 r.). W końcu III kwartału 1999 roku sieć ta obejmowała 1951 stacji benzynowych i 1363 sklepy (co stanowi największy potencjał usługowy wśród krajowych przedsiębiorstw handlowych). Natomiast CPN w 1998 r. skupiła $57 \%$ detalicznego rynku paliw;

- prasy, wydawnictw periodycznych i książkowych - ogólnokrajowa sieć ok. 30 tys. kiosków i sklepów należąca do przedsiębiorstwa Ruch SA, lidera na tym rynku.

Ważnym nurtem procesów koncentracji w przedsiębiorstwach handlowych z kapitałem krajowym są rozwijające się, ostatnio coraz intensywniej, różne formy zintegrowanych sieci handlowych.

Aktualnie na terenie kraju funkcjonuje ponad 30 znaczących zintegrowanych sieci handlowych, o zróżnicowanym udziale w rynku, zasięgu działania, różnej wielkości zasobów. Najczęściej przyjmują postać grup zakupowych o statusie stowarzyszeń kupieckich lub spółek kapitałowych (akcyjnych i z ograniczoną odpowiedzialnością). Do najważniejszych należą:

- Lewiatan Detal SA o zasięgu ogólnokrajowym i wyodrębniające się z niego regionalne sieci handlowe z artykułami żywnościowymi, dysponujące centrami dystrybucyjnymi lub logistycznymi, z których znaczącą rolę spełniają obecnie Lewiatan Kujawy i Lewiatan Łódź;

- Krajowa Agencja Handlowa i dziewięć agencji regionalnych „Spolem” tworzące zintegrowany system zaopatrzenia zrzeszonych w Krajowym Związku Rewizyjnym spółdzielni spożywców oraz łańcuchy sklepów Lux, sklepów dyskontowych S i spółdzielczych domów handlowych, funkcjonujące w spółdzielniach na terenie całego kraju;

- również o zasięgu ogólnokrajowym zintegrowana sieć drogerii, supermarketów i innych sklepów (glównie spożywczych) Delko SA;

- ogólnokrajowa sieć handlu artykułami żywnościowymi Centralnego Biura Zakupów Sp. z o.o. (CBZ) i związana z nim sieć spółki akcyjnej Sklepy Familijne;

- ponadregionalne i regionalne sieci handlowe: Grupa DSH, Chata Polska, Unia, Rabat, Lider (na ogół z artykułami żywnościowymi);

- stowarzyszenia detalistów o charakterze subregionalnym i lokalnym: Arena (Wrocław), Market Grosik (woj. lubuskie), Orbita (Olsztyn), Mini Europa (Warszawa), Va Bank (Elbląg), Viki (Gniezno), Tęcza (Konin).

Niektóre z wymienionych sieci zintegrowanych, tj. Chata Polska, Lewiatan, Sklepy Familijne i Centralne Biuro Zakupów, Rabat, Lider funkcjonują według zasad franchisingu lub zbliżonych do franchisingu. 
Sieci zagraniczne i zintegrowane sieci handlowe z kapitałem krajowym różnicuje oprócz wielkości zasobów również charakter i ścisłość związków integracyjnych.

Sieci zagraniczne, bẹdąc zazwyczaj częścią koncernów miẹdzynarodowych, łączy z tymi koncernami integracja kapitałowa. W związku z tym koncern wykonuje funkcje nadzoru właścicielskiego i koordynacyjne w stosunku do tych sieci.

Z badań wynika, że koncerny macierzyste w stosunku do swoich spólek filii w Polsce spełniają funkcje związane z zarządzaniem strategicznym oraz koordynują kluczowe dziedziny działalności tych spółek. Do podstawowych funkcji zarządczych i zadań koncernów najczẹśsiej należą:

- analiza i ocena działalności spólki,

- określanie kierunków jej rozwoju, wynikających z ogólnej strategii koncernu,

- przydział środków wspierających rozwój spółki, a w tym środków inwestycyjnych,

- obsadzanie stanowisk kierowniczych w spółce i określanie dla niej zasad polityki kadrowej.

Z innych zadań - badani menedżerowie spółek-filii koncernów - wymieniają takie, jak: nadzór nad podejmowaniem przez spółkę nowej działalności lub wręcz określenie obszaru tej działalności, sterowanie transferem know-how, zarządzanie udziałami w spółce według uzgodnionych zasad z jej właścicielami, likwidowanie dotychczasowej działalności spółki w określonych obszarach rynku, wybór nowych kanałów dystrybucji.

Funkcje koordynacyjne koncernu w stosunku do zarządu spółki obejmują jej kluczowe dziedziny działalności, dotyczące: badań rynkowych, marketingu, finansów i controllingu strategicznego.

Znaczna koncentracja kapitałowa i silna integracja organizacyjna spółek zagranicznych z koncernem macierzystym sprawia, że spółki te wyróżniają się na rynku polskim. Wplywa to m.in. na ocenę ich pozycji rynkowej. Większość badanych spólek w opinii ich menedżerów ocenia swoją pozycję rynkową jako co najmniej równoważną z konkurentami lub silniejszą od konkurentów. Opinie te wyrażają dwie niemal równoważne grupy menedżerów spółek, co powoduje marginalizację ocen - z jednej strony negatywnych i z drugiej - bardzo pozytywnych pozycji rynkowej spółek.

W przeciwieństwie do spólek zagranicznych grupy przedsiębiorstw rodzimych, tworzących zintegrowane sieci handlowe, opierają swoją wspólprace na integrowaniu wspólnych celów i wspólnym wykonywaniu określonych funkcji i zadań zapewniających realizację tych celów, według uzgodnionych warunków w umowie. W większości przypadków lączy te sieci współpraca w dziedzinie zakupów, rzadziej na innych płaszczyznach działalności.

Z badań wynika, że w zdecydowanej większości zintegrowanych sieci krajowych wykonywane są przez integratora grupy wspólne funkcje i zadania odnoszące się do czterech podstawowych dziedzin działalności, tj. promocyjnej, związanej z zakupami, edukacyjno-szkoleniowej i związanej z kształtowaniem standardów obsługi klientów. 
Integratorzy realizują ponadto niektóre zadania dotyczące wspólnej strategii rozwoju oraz badań marketingowych. Często również do centralnie wykonywanych zadań należą: organizacja badań rozwojowych, strategie rozwoju w określonych sektorach rynku, ustalanie standardów asortymentowych dla sklepów.

W niewielu natomiast przypadkach integratorzy prowadzą wspólną politykę cen i marź, zarządzają zapasami oraz kreują własne marki towarowe.

Mimo wielu ograniczeń zakresu i charakteru wspólpracy zintegrowane sieci handlowe z kapitałem krajowym, funkcjonujące od 2-3 lat, osiągają już pewne korzyści. Z badań wynika, że przede wszystkim osiągają korzyści wynikające ze skali działania, podnosząc przy tym standard uslug. Ponadto skutecznie bronią się przed konkurencją i rozszerzają swoją działalność na rynku. Uzyskują wzrost obrotów i udziałów w obsługiwanym rynku. Umacniają przy tym markẹ integratora. Często podkreśla się, że w wyniku integracji pew. nych funkcji zarządczych na szczeblu centralnym następuje usprawnienie funkcjonowania całej grupy i obniżenie kosztów działalności poszczególnych uczestników sieci. W minimalnym natomiast stopniu integracja przyczynia się do zwiększenia ich dostępu do nowoczesnych technik i technologii.

Niezbyt duże doświadczenia zintegrowanych sieci handlowych, ujawniają różne trudności zarówno w procesie kreowania, jak też i w toku funkcjonowania tych sieci. Badania wykazują, że najtrudniejszymi do spełnienia przez uczestników sieci warunkami jakie stawia tym uczestnikom integrator są:

- posiadanie własnego biznes-planu,

- udokumentowana wiarygodność finansowa,

- określony poziom obrotów rocznych w okresie poprzedzającym przystąpienie do sieci,

- podporządkowanie się określonym standardom świadczenia usług,

- atrakcyjna, specjalnie dobrana do potrzeb klientów, oferta towarowa.

Niektóre sieci zintegrowane zamierzają pogłębiać konsolidację, co jest zjawiskiem pozytywnym. Deklarowane w ramach badań zmiany polegać bẹdą przede wszystkim na:

- rozbudowie sieci i zwiększeniu jej potencjału usługowego,

- tworzeniu grup kapitałowych o różnym zasięgu terytorialnym działalności,

- pełnym wprowadzeniu zasad franchisingu.

Trzeba podkreślić, że kierunki tych zmian są zbieżne z tendencjami występującymi wśród zintegrowanych sieci handlowych w krajach wysoko rozwiniętych gospodarczo, ale skala działań konsolidacyjnych jest nadal zbyt mała.

\section{Podsumowanie i wnioski}

Wyniki badań wykazują, że na przebieg procesów koncentracji w handlu detalicznym w Polsce zwłaszcza od połowy lat dziewięćdziesiątych coraz wiekszy wpływ wywierają sieci zagraniczne. Chociaż skala koncentracji, wyrażona udziałem rynkowym przedsiębiorstw największych (o obrotach od $100 \mathrm{mln} \mathrm{zl}$ ) 
jest niewielka (15,9\% w 1998 r.), to jednak znaczący wpływ na nią mają spólki z kapitałem zagranicznym. One właśnie skupiają prawie połowę sprzedaży najwiẹkszych podmiotów handlowych.

Generalnie obserwuje się dwa charakterystyczne trendy koncentracji, tj. rozwój spółek z sieciami filialnymi koncernów globalnych oraz rozwój zintegrowanych sieci w postaci systemów franchisingowych lub zrzeszeń niezaleźnych detalistów.

Największą dynamiką rozwoju charakteryzują się sieci globalne na rynku artykułów żywnościowych w postaci sieci filialnych, międzynarodowych systemów franchisingowych i zrzeszeń detalistów.

Są to przede wszystkim lańcuchy sklepów masowej sprzedaży, tj. hipermarketów, supermarketów, sklepów dyskontowych; także lańcuchy sklepów wyspecjalizowanych, głównie w niszach rynkowych.

Stosunkowo mniejszą koncentracją charakteryzują się sieci spólek zagranicznych na rynku artykulów nieżywnościowych. Obok rozproszonej i wielokierunkowej działalności występują tendencje do wyraźnie ukierunkowanego rozwoju lańcuchów sklepowych w sektorach rynku o największej dynamice zmian, tj. rynku artykułów:

- do wyposażenia i wykończenia wnẹtrz mieszkalnych, domu i ogrodu,

- odzieżowo-obuwniczych,

- zaspokajających potrzeby rekreacji, wypoczynku, rozrywki, hobby, kulturalne.

W wymienionych sektorach rozwijają się stopniowo sieci wyspecjalizowane, a w tym przede wszystkim o specjalizacji problemowej i wielkopowierzchniowe (supersklepy). Są to sieci jeszcze o niewielkim potencjale usługowym, ale o dużych perspektywach rozwoju.

Zaznacza się także trend rozwoju sieci zdywersyfikowanych, należących do najwiẹkszych koncernów światowych, jak np. Metro AG z sieciami hipermarketów Real, supersklepów Dom i Ogród (Praktiker), sklepów multimedialnych Media Markt, ze sprzętem komputerowym i oprogramowaniem Vobis, z modną odzieżą Adler. Sieci zdywersyfikowane charakteryzują się dużą koncentracją kapitałową, ale zróżnicowanym stopniem ważności w strategii rozwoju koncernu.

$\mathrm{Na}$ tle postępujących procesów koncentracji w sieciach zagranicznych zbyt słabo przebiega konsolidacja sieci z kapitałem krajowym. Aktualnie występuje tylko kilka liczących się ogólnokrajowych sieci filialnych z kapitałem rodzimym, np. Ruch, Polski Koncern Naftowy, Market Pozperito, Komfort oraz kilkanaście o charakterze regionalnym i lokalnym (głównie sieci spóldzielni spożywców). Perspektywy rozwoju krajowych sieci filialnych w ramach koncentracji kapitałowej są niewielkie, głównie z powodu ograniczeń zasobów kapitałowych i moźliwości inwestycyjnych przedsiębiorstw.

Mogą one jednak ulec radykalnej zmianie w przypadku podejmowania coraz śmielszych inicjatyw integracyjnych. Nie należy przy tym wykluczać projektów integracji zarówno kapitałowej, jak i organizacyjnej, polskich przedsiębiorstw ze spółkami z kapitałem zagranicznym. 
Aktualnie procesy integracyjne polskiego kupiectwa mają ograniczony zakres i zasięg działania. Wciąż jest to początkowa faza ich rozwoju. Obecnie bowiem w handlu detalicznym funkcjonuje nieco ponad 20 liczących się zintegrowanych sieci handlowych. Charakter i ścisłość związków integracyjnych w funkcjonujących sieciach są zróżnicowane. Inicjatywy integracji kapitałowej należą do rzadkości. W świetle dotychczasowych tendencji można sądzić, że pogłębiać się będą procesy integracji organizacyjnej. Intensywność i skala tych procesów zależeć będą od świadomości polskiego kupiectwa odnośne konieczności integrowania się i tym samym sprostania konkurencji sieci zagranicznych.

Przebieg natomiast procesów koncentracji w sieciach zagranicznych będzie uzależniony przede wszystkim od postępu prac nad reformowaniem naszej gospodarki i jej integracja z jednolitym rynkiem europejskim, klimatu dla inwestycji zagranicznych, rozwoju społeczno-gospodarczego kraju.

W 1999 r. zaobserwowano zwolnienie tempa inwestycji zagranicznych w związku z przejściowo zaostrzającą się sytuacją społeczno-gospodarczą w Polsce. Niemniej jednak prognozy gospodarcze, zwłaszcza formułowane przez niezależnych analityków i ośrodki badawcze zagraniczne, są optymistyczne. Moźna zatem przypuszczać, że postępował bẹdzie rozwój bezpośrednich inwestycji zagranicznych w Polsce. Przyjmując, że zgodnie z deklaracjami inwestorów zagranicznych ich udział w inwestycjach handlowych bẹdzie rósł można sądzić, że nastąpi dalszy rozwój sieci zagranicznych oraz pogłębianie procesów koncentracji w handlu.

Wydaje się, że w perspektywie kilkuletniej (zanim kraj nasz znajdzie się w strukturach Unii Europejskiej) konsolidacja i koncentracja handlu detalicznego przebiegać będzie przede wszystkim w nastẹpujących kierunkach:

- coraz bardziej zwiększał się będzie udział rynkowy wąskiej grupy przedsiębiorstw o największych zasobach i potencjale ekonomicznym przy jednoczesnej selekcji i eliminacji z rynku podmiotów nieefektywnych, niezdolnych do konkurowania, o zbyt małych zasobach i umiejętnościach do integrowania się. Wydaje się, że podstawową grupę podmiotów o największych udziałach rynkowych stanowić bẹdą w dalszym ciągu koncerny zagraniczne z filialnymi sieciami handlowymi. Wzmocni się przy tym pozycja niektórych rodzimych przedsiębiorstw rozwijających sieci handlowe, ale przede wszystkim na rynkach regionalnych i lokalnych;

- nastąpi dalszy rozwój przedsiębiorstw z sieciami handlowymi w różnych sektorach rynku o największej dynamice rozwojowej. Tempo rozwoju tych sieci uzależnione będzie od intensywności zmian na rynku w powiązaniu z procesami globalizacyjnymi, sytuacji popytowo-podażowej, zwłaszcza dotyczącej siły nabywczej polskich konsumentów, zmian w ich stylu życia, preferencji i zwyczajów w dokonywaniu zakupów, a także zmian w metodach i instrumentach zarządzania w przedsiębiorstwach. Szczególną rolę spełniać będą realizowane przez te przedsiębiorstwa strategie merchandisingowe, w ramach których określoną rangę zyskają innowacyjne formy 
handlu i metody obsługi konsumentów, dyskontujące nowoczesne technologie i techniki przede wszystkim teleinformatyczne. Wydaje się, że sieci zagraniczne spełniać będą w tym zakresie rolę wiodącą;

- kontynuowany będzie dalszy intensywny rozwój sieci sklepów tzw. masowej sprzedaży, tj. hipermarketów, supermarketów i sklepów dyskontowych żywnościowych. Wśród sieci hipermarketów i sklepów dyskontowych dominować będą nadal sieci spółek z kapitałem zagranicznym. Do grona tego dołączą niektóre sieci krajowe. Natomiast sieci supermarketów rozwijane będą przez różne ogólnokrajowe, regionalne i lokalne przedsiębiorstwa z kapitałem krajowym, zagranicznym i mieszanym;

- postępowała bẹdzie dyferencjacja sieci w różnych sektorach branżowych rynku artykułów nieżywnościowych, głównie dzięki spółkom z kapitałem zagranicznym. Ich udział prawdopodobnie zwiększy się na rynkach: artykułów do wnętrz mieszkalnych i ogrodu, odzieżowo-obuwniczym, artykułów zaspokajających potrzeby rekreacji, sportu, kulturalne, a także zaznaczy się na nowych segmentach rynku o dużym potencjale rozwojowym;

- w związku z rozwijającymi się procesami koncentracji w sieciach zagranicznych nastąpi wyraźny postęp w podejmowaniu różnych inicjatyw integracyjnych przedsiębiorstw z kapitałem krajowym. Zaowocuje to rozwojem zintegrowanych sieci handlowych przede wszystkim o charakterze zrzeszeń i grup zakupowych, a w dalszej kolejności systemów quasi franchisingowych i franchisingowych. Trzeba się liczyć z faktem, że inicjatywy te będą wspierane przez zintegrowane sieci zagraniczne. Polskie przedsiębiorstwa nie powinny wykluczać współpracy z nimi.

Zarysowane główne kierunki prawdopodobnych zmian w ostatecznym rachunku bẹdą uzależnione od stopnia otwarcia się polskiej gospodarki na procesy globalizacyjne, a w tym - od możliwości adaptacyjnych i antycypacyjnych prawidłowości koncentracji i integracji w handlu i na rynku w wymiarze europejskim i światowym. 